\title{
Proposed Changes in Federal Taxation of Community Property: Estate and Gift Taxes*
}

George E. Ray†

\section{ESTATE TAX}

$T_{\text {HE problem of the effect of the community property system on the }}$ federal estate tax has not attracted nearly as much attention as has the problem of the effect of the system upon the federal income tax. The two questions bear a considerable similarity since the community property system may be said to afford the opportunity to taxpayers in community property states to pay lesser amounts in estate taxes than do taxpayers in non-community property states similarly situated but holding their property as the separate property of the husband rather than as community property. ${ }^{1}$ In noncommunity property states the husband's separate property is subjected to the federal estate tax without division between the spouses. On the other hand, in the community property states as a rule only one-half of the community property is includable in the husband's estate upon his death.

In non-community property states husbands and wives can divide their property between theniselves for estate tax purposes, as well as for income tax and gift tax purposes, by holding title to the property as separate property or as tenants in common. If, however, the spouses hold their property as tenants by the entirety or as joint tenants they may find difficulty in dividing the property between theniselves for estate tax purposes, unless they can prove that each spouse brought in one-half of the property. In view of the fact that spouses in non-community property states may set up tenancies in common which, for estate tax purposes, afford an opportunity to them to divide their property between themselves as their separate property in whatever ratios they choose, the discrimination against spouses

*The first instaliment of this article, Proposed Changes in Federal Taxation of Community Property: Income Tax, appeared in (1942) 30 CALIF. L. REV. 397.

tMember of the Massachusetts and New York Bars; A.B., LI.B., Harvard University. Author of articles in various legal periodicals.

I See I Paud, Federal Estate and Gift Taxation (1942) \$1.09. 
in those states and in favor of spouses in community property states arises principally from the fact that in the non-community property states a gift tax may have to be paid on the inter-spouse transfer, whereas in the community property states such a transfer would not be necessary to transform earnings of the marital community into community property.

Three principal differences exist in the possible estate tax burdens of spouses in non-community property states and those in community property states with respect to property all of which has been earned by the husband: (1) The difference between the tax on a given amount and a tax on half that amount, where the husband dies first and the wife is to have all the property, since the tax in a non-community property state is on all the family property and in a community property state it is on only one-half of the property. (2) The difference between the tax on a given amount and twice the tax on one-half of that amount, where a child is to receive all the property passing at the death of either parent, since in a non-community property state the tax is levied on all the property upon the father's death and in a community property state one-half of the property is taxed at the death of each parent. (3) The difference between the tax on one-half of the given amount and no tax at all, where the wife dies first and the husband is to have all the property, since in a non-community property state there is no tax and in a community property state one-half of the property is taxed upon her death."

\section{Differences between the Incidence of. Federal Estate Taxation in Community Property States and in Other States}

Ordinary property.-In the non-community property states ordinary property is generally included in the estate of the person holding legal title thereto. ${ }^{3}$ In the case of certain transfers during the decedent's life, however, in contemplation of death, taking effect at death, or revocable, the property may be included in the estate of the transferor. The decedent's gross estate also includes dower or curtesy, or interests in lieu thereof; the entire value of any property in which he held an interest in joint tenancy or tenancy by the entirety, except to the extent the property is shown to have originally

2 This disadvantage of the community property system was poimted out by Senator Overton of Louisiana in the Senate debate on the Finance Committee draft of the Revenue Bill of 1941. (1941) 87 CoNg: Rec. 7519.

3I. R. C. \& 811 (a). Porter v. Commissioner (1933) 288 U. S. 436. 
belonged to the survivor and to have been received by the survivor for an adequate and full consideration, in money or money's worth, and property passing under a general power of appointment exercised by the decedent. ${ }^{4}$ Property held by the decedent as a tenant in common is only includable in the decedent's estate to the extent of the interest of the decedent. ${ }^{5}$

In the community property states the estate tax liability with respect to property which constitutes the separate property of one of the spouses is the same as in the non-community property states. ${ }^{6}$ With respect to community property the general rule is that one-half of the property is subject to estate tax on the death of the husband and the other half of the community property is subject to estate tax upon the death of the wife. ${ }^{T}$ This general rule applies in California (as to property acquired after July 29,1927$),{ }^{8}$ Arizona, ${ }^{9}$ Texas, ${ }^{10}$ Idaho, ${ }^{11}$ Louisiana, ${ }^{12}$ Washington ${ }^{13}$ and Oklahoma. ${ }^{14}$ Each of the community property states has its own peculiarities modifying this general rule. In New Mexico the wife's interest in community property is held to be obliterated by her death and no part thereof is includable in her gross estate. ${ }^{15} \mathrm{~A}$ similar result was reached prior to 1935 in Nevada, ${ }^{16}$ but since 1935 the rule has been that the entire community property goes to the survivor whether husband or wife. ${ }^{17}$ In Louisiana the wife's half of community property in case of her intestacy descends to her heirs. ${ }^{18}$ It has been held in that state that the value of the widow's life usufruct (similar to a life estate) in the husband's share of the community property is not deductible from

II. R. C. \$ 811 .

5 Estate of Irwin A. Smith (1941) 45 B.T. A. 59.

6 Beals v. Fontenot (C. C. A. 5th, 1940) 111 F. (2d) 956.

71 PaUr, op. cit, supra note $1, \S 4.11$; T. D. 3138,4 C. B. $238, \bmod$., T. D. 3569 , III-1 C. B. 91 .

8 United States v. Goodyear (C. C. A. 9th, 1938) 99 F. (2d) 523.

0 See ARIz. CoDE (1939) § 39-109.

10 G. C. M. 7733 , IX-2 C. B. 426.

11 Shaw v. MeDougall (1936) 56 Idaho 697, 58 P. (2d) 463.

12 See LA. Crv. CoDE (Dart, 1932) $\$ \S 915,916$.

13 WASH. REv. StaT. (Remington, 1932) § 1342.

14 Okra. Stat. (Supp. 1941) tit. 32, § 65.

15 N. M. STAT. (Courtright, 1929) \$38-104; Hernandez v. Becker (C. C. A. 10th, 1931) 54 F. (2d) 542. This case was decided under the 1921 Act, however, which required that the decedent's interest be subject to administration expenses and charges against the estate and distributed as part of the estate.

16 NEv. Cosrp. LAws (Hillyer, 1929) §3364.

17 Nev. Stats. 1935, p. 232, c. 110.

18 Bossier v. Herwig (1904) 112 La. 539, 36 So. 557. 
the half of the community property going to the heirs of the deceased husband for the purpose of computing the federal estate tax. ${ }^{10}$ In Texas the wife's interest in community property is not a part of the deceased husband's gross estate. ${ }^{20}$

In California, since community property for federal tax purposes did not exist prior to July 29, 1927, property acquired prior to that date is all includable in the estate of the husband. ${ }^{21}$. Where spouses in California entered into an agreement vesting in the wife a "present, existing and equal interest" in property acquired by the husband prior to July 29,1927 , and the husband died after that date, only one-half of the property owned by him prior to the execution of the agreement was held includable in his estate. ${ }^{22}$ In Oklahoma the community property law, effective July 29, 1939, provides that a husband and wife may by filing a written election hold as community property, property acquired after the date of signing the election but not acquired prior thereto. ${ }^{23}$

In a case involving a decedent who was a citizen of Spain, ${ }^{24}$ only one-half of the value of certain stocks, bonds and cash in the United States was held includable in the gross estate, because under the Spanish Civil Code the interest of a deceased spouse is a one-half interest only. So as to a decedent domiciled in the Philippines. ${ }^{25}$

Life insurance.-In the non-community property states the proceeds of life insurance taken out by the decedent upon his own life are part of his gross estate to the extent of the amount receivable by the executor and to the extent of the excess over $\$ 40,000$ of the

19 Liebman v. Fontenot (W. D. La. 1921) 275 Fed. 688. Cf. Beals v. Fontenot, supro note 6. See 1 PAUx, op. cit. supra note $1, \S 5.05$.

20 G. C. M. 7773, IX-2 C. B. 426. Cf. Stewart v. Commissioner (C. C. A. 5th, 1933) 63 F. (2d) 62; George W. Burkitt Estate (1926) 3 B.T. A. 1158. Similarly in Washington. Pacific Nat. Bank of Seattle, Executor (1939) 40 B.T.A. 128.

21 Estate of Alfred S. Gump (1940) 42 B.T.A. 197, affd, (C.C.A. 9th, 1941); T. D. 3891, V-2 C. B. 232. But cf. Wardell v. Blum (C. C. A. 9 th, 1921) 276 Fed. 226.

22 United States v. Goodyear, supra note 8; Alice A. Bigelow, Executrix (1929) 39 B.T. A. 635. Cf. Bank of America Nat. Trust \& Sav. Ass'n v. Rogan (S. D. Cal. 1940) 33 Fed. Supp. 183; Sampson v. Welch (S.D. Cal. 1941) 40 Fed. Supp. 1014. See 1 Pavr, op. cit. supra note 1, \& 4.11; Mitchell, Federal Taxation in Recent Contact with Califormia Community Property (1941) 14 So. CALIF. L. Rev. 390, 392-6.

23 Okla. Sess. Laws 1939, c. 62, art. 2, § 1.

24 Estate of Jose Simon (1939) 40 B.T. A. 651.

25 Commissioner v. Cadwallader (C. C. A. 9th, April 30, 1942) 127 F. (2d) 547 ; cf. Sanchez v. Bowers (C. C. A. 2d, 1934) 70 F. (2d) 715 (Cuban law); 1 PAUL, op. cit. supra note $1, \S 2.15$. 
amount receivable by all other beneficiaries. ${ }^{26}$ The importance of the source of the premium payments, as against the retention by the decedent of "incidents of ownership" in the policy, is unsettled. The Court of Claims has held that where the decedent provided for the reversion of the ownership to himself in case he survived certain designated beneficiaries, the proceeds of the policies were includable in his estate, despite the fact that an assignee of the policies had paid all of the premiums subsequent to the assignment. ${ }^{27}$

Where premiums on policies of insurance on the decedent's life were paid out of community property in Washington, the Supreme Court held that only one-half of the proceeds of the policies should be included in decedent's estate. ${ }^{28}$ Similarly, in Louisiana, ${ }^{29}$ Texas $^{30}$ and California. ${ }^{31}$ If when the question reaches the Supreme Court the source of the payment of the premiums is held to be the determining factor, then it would appear that in the community property states the rule of the cases decided with respect to Louisiana and Washington community property will be applicable to insurance taken out by residents of any of the other community property states.

Expenses and claims against the estate.-In the non-community property states claims against the decedent's estate and funeral expenses and expenses of administering the estate are deductible in computing the net estate. ${ }^{32}$ The rule in the community property states, however, is far from clear. It has been held that only one-half of the funeral expenses and claims against the estate of a decedent who was a resident of Washington were deductible in computing his estate since they were claims against and expenses of the community. ${ }^{33}$

${ }^{26}$ I. R. C. $\$ 811$ (g).

27 Bailey v. United States (Ct. Cl. 1940) 31 Fed. Supp. 778. Under Chase Nat. Bank v. United States (C. C.A.2d, 1940) 116 F. (2d) 625 , and T. D. 5032, 1941-1 C. B. 427 (insurance taken out after January 10,1941) the test of taxability of insurance payable to beneficiaries other than the decedent's estate is whether the decedent paid the premiums, while any insurance payable to the decedent's estate is property of the decedent, includable as such under the general provisions of the estate tax. See Warren, Correlation of Gift and Estate Taxes (1941) 55 HaRv. L. REv. 1.

28 Lang v. Commissioner (1938) 304 U. S. 264.

29 DeLappe v. Commissioner (C. C. A. 5th, 1940) 113 F. (2d) 48.

30 Estate of Shearn Moody (1940) 42 B.T.A. 987; Estate of Oscar Levy (1940) 42 B. T. A. 991.

31 Elizabeth C. McCoy, Admin. (1939) 39 B. T. A. 822. See 1.PAuL, op. cit. supra note $1, \S \S 10.27,10.28$.

32 I. R. C. $\$ 812(\mathrm{~b})$.

33 Lang's Estate v. Commissioner (C. C. A. 9th, 1938) 97 F. (2d) 86\%. [This point was not before the Supreme Court on appeal in (1938) 304 U. S. 264.] Pacific Nat. Bank of Seattle, Executor, supra note 20. 
But it has been held that in determining the value of the estate of a resident of Texas for federal estate tax purposes, the entire amount of the funeral expenses of the decedent may be deducted from his share of community property in Texas. ${ }^{34}$ Where only one-half of the attorney's fees for administration of the decedent's estate were attributable to his portion of Texas community property, it has been held that only one-half of the expenses were deductible, ${ }^{35}$ but where the attorney's fees and expenses were deemed administration expenses against the decedent's half of the community only, they have been held deductible in full fron his gross estate in Washington. ${ }^{36}$

\section{Proposed Solutions}

Reversal of Poe v. Seaborn.-Under the present estate tax law, with its specific enumeration of what items go into making up the decedent's gross estate, community property is not expressly included. Specific classifications into which community property might conceivably fall are those requiring the inclusion in the gross estate of dower or curtesy interests ${ }^{37}$ and interests held in joint tenancy or tenancy by the entirety. ${ }^{38}$ The provisions dealing with transfers in contemplation of death or taking effect at or after death ${ }^{30}$ are clearly ina'dequate to deal with the comnunity property problem. ${ }^{40}$ It has been held that the interest of a wife in community property does not constitute dower or an estate in lieu of dower. ${ }^{41}$ Community property does not fall within the provisions relating to interests as joint tenants or tenants by the entirety since it is clearly a form of property holding entirely separate and distinct from joint tenancy or tenancy by the entirety..$^{2}$ The express enumeration of the latter two forms of hold-

34 Blair v. Stewart (C. C.A. 5th, 1931) 49 F. (2d) 257. Cf. Stewart v. Commissioner (C. C. A. 5th, 1933) 63 F. (2d) 62 ; see 1 PAUt, op. cit. stupra note 1 , $\$ \$ 11.10$, $11.18,11.25$.

35 Estate of Oscar Levy, supra note 30.

${ }^{36}$ Lang's Estate v. Commissioner, supra note 33. Cf. Commissioner v. Strauss (C. C. A. 7th, 1935) 77 F. (2d) 401, B.T.A. Memo. Op. aff'd, (C. C. A. 7th, 1936) 81 F. (2d) 1016.

at I. R. C. $\S 811(b)$.

38 I. R. C. $\S 811$ (e). See 1 PAUL, op. cit. supra note $1, \S \S 1.09,5.05,8.08$.

30 I. R. C. $\$ 811$ (c), (d).

10 See 1 PaUr, op. cit. supra note $1, \S 7.31$.

41 See Sampson v. Welch (S. D. Cal. 1938) 23 Fed. Supp. 271, 282, overruled on another point, supra note 22 . But $c f$. as to the husband's "marital portion" of his wife's estate under Louisiana law. Hernandez v. Becker (C. C. A. 10th, 1931) 54 F. (2d) 542 ; Estate of Nellie Grant Burbank Dodge (1939) 40 B.T. A. 209.

42 See 1 PAUL, op. cit. supra note $1, \S \S 1.09,8.08$; cf. T. D. 3138,4 C. B. 238. 
ing, without the express inclusion of community property or tenancy in common, constitutes a clear indication of congressional intent that no interests other than those expressly referred to in the statute should be included. If in order to prevent the division of property by spouses in community property states for estate tax purposes community property is to be treated in the same manner as property held in joint tenancy or tenancy by the entirety, an express provision by amendment of the estate tax law appears necessary.

Community property falls within the general clause of the estate tax providing that the value of the gross estate of the decedent shall be determined by including the value at the time of his death of all property "To the extent of the interest therein of the decedent at the time of his death. . . ."43 The Supreme Court has held that the term property in this clause relates to legal title which passes at death, and since the husband has title to only one-half of the community property only one-half is includable in his estate. If Poe v. Seaborn ${ }^{45}$ were to be overruled under the income tax, there would seem little doubt that a similar change would take place with respect to community property under the estate tax. In view of the language of the Supreme Court in Helvering v. Hallock $k^{46}$ concerning "refined technicalities of the law of property" as they affect the estate tax, it would appear that the Court would have little trouble in abandoning Poe $v$. Seaborn for its earlier decision in United States $v$. Robbins ${ }^{47}$ as a criterion under the estate tax on the ground that estate-tax consequences should not hinge upon the distinction between a "vested interest" and an "expectancy".4 However, since the better course to follow under the income tax appears to be resort to legislation rather than a reversal of Poe v. Seaborn, it is desirable to consider legislative proposals for renedy of the community property situation under the estate tax.

Five principal types of legislative proposals for the solution of the community property problent under the estate tax suggest themselves: (1) taxation of community property in a inanner similar to that applicable to property held in tenancy by the entirety or joint tenancy; (2) taxation of the entire aniount of the community prop-

43 I. R. C. $\$ 811$ (a).

14 Porter v. Commissioner, supra note 3.

45 (1930) 282 U. S. 101.

16 (1940) 309 U. S. 108.

47 (1926) 269 U. S. 315.

19 See 1 PAUL, op. cit. suppa note 1 , at 59. 
erty to the spouse first dying; (3) taxation of both community property and property held in tenancy in common in a manner similar to that applied at the present time to property held in joint tenancy or tenancy by the entirety; (4) inclusion of all the property of spouses, in whatever form held in the estate of the spouse first dying, and (5) inclusion of half the property of spouses, in whatever form held, in the estate of each spouse.

Taxation of community property in a manner similar to that applicable to property held in joint tenancy or tenancy by the entirety. -The proposal would add a new subsection to section 811 of the Internal Revenue Code to provide that the value of the gross estate of the decedent should include all property ${ }^{40}$ to the extent of any interest therein held as community property by the decedent and spouse, except such part thereof as may be shown to have originally belonged to the surviving spouse and never to have been received or acquired by such surviving spouse from the decedent for less than an adequate and full consideration in money or money's worth (determined without regard to the law of any state, territory or possession of the United States or of any foreign country dealing with the marital community); provided that where such property or any part thereof, or part of the consideration with which such property was acquired, is shown to have been at any time acquired by the surviving spouse from the decedent for less than an adequate and full consideration in money or money's worth, there shall be excepted only such part of the value of such property as is proportionate to the consideration furnished by such surviving spouse. It would seem desirable to limit the proposal so that it would apply only to the estates of decedents dying after the date of the enactment of the Revenue Act of 1942, thus giving it prospective effect only.

It should be noted that in the case of interests held in joint tenancy the law does not require that the interest be held by the decedent in joint tenancy with his or her spouse but merely requires that the interest be held as joint tenants by the decedent and "any other person".50 The interest held in tenancy by the entirety must, of course, be held by the decedent and his or her spouse. In the case of community property the situation would be thus similar to that of a

49 Subject to the overall limitations of section 811, "... real or personal, tangible or intangible, wherever situated, except real property situated outside of the United States."

50 I. R. C. $\$ 811(\mathrm{e})$. 
tenancy by the entirety rather than a joint tenancy, since community property can exist only in the case of spouses. It may also be noted in this respect that a tenancy in common is similar to a joint tenancy rather than to a tenancy by the entirety or to the interest of spouses in community property.

Two principal arguments might be urged against the proposal by the residents of community property states: first, that it rests upon a fallacious assunption that coinmunity property is more like property held in jonit tenancy or tenancy by the entirety than like property held in tenancy in common; and second, that it would be unconstitutional as a denial of due process of law under the Fifth Amendment.

In an early ruling, the Treasury held that although in all coinmunity property states except California spouses could divide their community property for estate tax purposes, community ownership was governed by the specific provision relating to estates held jointly or by the entirety. ${ }^{51}$ In tenancies by the entirety and joint tenancies, as distinguished from tenancies in common, each tenant has an interest in all of the property, and upon the death of one of the tenants the survivor obtains the entire property. In a tenancy in common the survivor obtains only such portion of the property as represents his interest.

In the case of community property each spouse has an interest in the entire property, but the question of survivorship is one depending upon the particular state law. In Nevada, by statute, upon the death of either spouse the entire community property belongs to the survivor, except that a surviving husband who has abandoned his wife is entitled to only one-half of the property. ${ }^{52}$ In New Mexico the entire property belongs to the husband on the death of the wife, while on the death of the husband the surviving wife is entitled to one-half of the community property. ${ }^{53}$ In Arizona, Idaho, Louisiana, Texas, Washington, California and Oklahoina, on the death of either spouse one-half of the community property renuaining after the payment of the conmunity debts goes to the surviving spouse. ${ }^{54}$ Generally, as to

51 T.D. 3138,4 C. B. 238.

52 NEv. CoNT. LAws (Billyer, 1929) $§ \S 3364,3365$, as amended by Nev. Stats. 1935, p. 232, c. 110 .

${ }_{53}$ N. M. STAT. (Courtrigbt, 1929) § 38-104; In re Chavez Estate (1929) 34 N. M. 258, 280 Pac. 241.

54 Kohny v. Dumbar (1912) 21 Idaho 258, 121 Pac. 544; Robinson v. McDonald (1854) 11 Tex. 385; ARIz. CodE (1939) §39-109; LA. CIv. Code (Dart, 1937) §\$ 915, 916; Okta. Stat. (Supp. 1941) tit. 32, § 65; Wase. Rev. Stat. (Remington, 1932) § 1342; see United States v. Goodyear (C. C. A. 9th, 1938) 99 F. (2d) 523. 
the one-half which belongs to the surviving spouse, he or she takes it by right of survivorship rather than by descent, succession or inheritance. ${ }^{55}$ The rights of the spouses in community property do not appear to be more similar to the rights of spouses as tenants by the entirety or joint tenants than to those of spouses as tenants in common. Community property seems to fall somewhere between the two categories. Consequently the proposal here under discussion is open to the objection that by treating community property as property held in joint tenancy or tenancy by the entirety it leaves tenancies in common as a means by which spouses may reduce their estate taxes. Since tenancy in common is available generally to the residents of both community property and non-community property states, no real discrimination against the residents of any particular state appears.

That the proposal would be unconstitutional as a denial of due process of law can hardly be maintained in view of Tyler $v$. United States, ${ }^{56}$ upholding the estate tax provision with respect to tenancies by the entirety, and Gwinn v. Commissioner ${ }^{57}$ and United States v. Jacobs, ${ }^{58}$ upholding the estate tax provision as to joint tenancies. Under the Tyler case the test would be "... not whether there has been, in the strict sense of that word, a 'transfer' of the property by the death of the decedent, or a receipt of it by right of succession, but whether the death has brought into being or ripened for the survivor, property rights of such character as to make appropriate the imposition of a tax upon that result (which Congress may call a transfer tax, a death duty or anything else it sees fit), to be measured, in whole or in part, by the value of such rights."

The proposal would also meet the test set forth by the Supreme Court in Klein $v$. United States, ${ }^{80}$ upholding the inclusion in the decedent's gross estate of property in which the decedent retained a reversion in fee, since it could be said that "... the death of the grantor was the indispensable and intended event which brought the larger estate into being for the grantee and effected its transmission from the dead to the living, thus satisfying the terms of the taxing

\footnotetext{
5511 Ax. JUR. 226.

56 (1930) 281 U. S. 497.

57 (1932) 287 U. S. 224.

68 (1939) 306 U. S. 363.

69 Supra note 56, at 503 .

60 (1931) 283 U. S. 231, 234.
} 
act and justifying the tax imposed." To the extent that the proposal could be said to prevent tax avoidance, its constitutionality finds support in Helvering v. City Bank Co. ${ }^{61}$ wherein the Supreme Court observed that "Congress may adopt a measure reasonably calculated to prevent avoidance of a tax."

Taxation of the entire community property to the spouse who dies first.-This proposal is inerely a inodification of the one already considered. Under the language of the Supreme Court in Tyler $v$. United States the proposal would appear constitutional in a situation where the husband died first, but considerably nore doubt might arise as to whether the wife's prior death would cause sufficient property rights to "ripen" to "... nnake appropriate the imposition of a tax upon that result ... ."62 In view of Helvering v. Hallock, ${ }^{63}$ however, it appears that the proposal would be held constitutional.

Under such a proposal, however, the residents of community property states would be singled out for estate tax purposes, and without similar treatment of tenancies by the entirety, tenancies in common and joint tenancies, the plan would appear too severe in its effect upon the residents of commumity property states to recommend enactment. It would tend to prevent such estate tax avoidance as now takes place through the use of the community property system, but since in the community property states spouses may hold property as the separate property of each spouse, estate tax avoidance in those states would certainly not be entirely abolished.

The taxation of community property and property held in tenancy in common in a manner similar to that applied at the present time to property held in joint tenancy or tenancy by the entirety.To tax both community property and property held in tenancy in common in a manner similar to that employed at the present time ${ }^{64}$ with respect to jonit tenancies and tenancies by the entirety would tend toward greater umformity of estate taxation and would, to some extent, prevent avoidance of the estate tax which now takes place through community property and tenancies in common. Such a proposal might be adopted with either of two alternative subordinate

61 (1935) 296 U. S. $85,90$.

62 Supra note 56, at 503 .

63 (1940) 309 U. S. 106.

ot I. R. C. §811(e). 
provisions: (1) Since joint tenancies and tenancies in common may exist between persons who are not spouses, the proposal inight apply to tenancies in common in exactly the same manner as the provision with respect to joint tenancies under section $811(\mathrm{e})$, with the use of the phrase "to the extent of the interest therein held as tenants in common by the decedent and any other person". Community property, on the other hand, would be treated in a manner similar to that einployed in section 811 (e) with respect to tenants by the entirety, with the use of the phrase "to the extent of the interest held as commumity property by the decedent and spouse". (2) The provision might be limited to the taxation of the property of spouses only, so that whether the holding be as joint tenants, tenants by the entirety, tenants in common or in community, the common wording would in all four cases be "to the extent of the interest therein held by the decedent and spouse". Since the history of the income, estate and gift tax laws is replete with instances of tax avoidance by transfers to persons other than the spouse of the transferor, it would appear that the former of the two alternative plans would be preferable.

In view of the lack of survivorship in the case of tenancies in common considerable doubt might arise as to the constitutionality of the proposal. The case of a tenancy in.common, however, does not appear far removed from that of a joint tenancy under which either tenant may sever the relationship thereby creating a tenancy in common. If the proposal were confined to tenancies between spouses its constitutionality could be supported on the ground that under the estate tax as well as under the gift tax spouses may be treated as a unit.

It may readily be noted that this proposal as well as the two previously considered leaves open the possibility for estate tax avoidance through the holding of property by spouses as the separate property of each spouse.

Inclusion of all the property of spouses, in whatever form held, in the estate of the spouse first dying.-This proposal would be the estate tax counterpart of mandatory joint returns under the income tax law and it would be open to the same objections. The constitutional problem involved is similar to that arising under the income tax law, namely, whether Congress may tax the family as.a unit. Parenthetically, it may be noted that if this proposal were adopted it would probably be desirable to extend to tenancies in common and 
community property the treatment now given to joint tenancies under the Internal Revenue Code ${ }^{65}$ namely, to tax as part of the decedent's estate property held in community or tenancy in common with any other person, except to the extent that the property is shown to have originally belonged to the other person and never to have been received or acquired by him from the decedent for less than an adequate and full consideration in money or money's worth. If mandatory joint returns under the income tax are to be required then consideration of the taxation of spouses as an entity under the estate tax would appear to be in order. This proposal appears at first to be much more revolutionary than that for mandatory joint returns under the income tax law. If, however, the family is to be treated as a taxable unit under the mcome tax law it would appear desirable to extend that treatment into the estate tax law and, as will be noted later, the gift tax law. The proposal would bring about the elimination of discrimination between residents of different states arising from differences in the forms of property holding under the various state laws and would eliminate the possibility of tax avoidance by interspouse transfers of property. These are the two principal objectives of mandatory joint returns under the incoine tax law.

Inclusion of half the combined property of spouses in whatever form held, in the estate of each spouse.-This proposal, applying to spouses living together at the time of the death of the spouse first dying, would be the estate-tax counterpart of the proposal to permit all spouses to divide their combined incomes for income tax purposes and would apply to all the property of spouses in every state the rule that now applies only to community property in some states. As in the case of the corresponding income tax proposal, the plan would result in a considerable loss of revenue unless there were a substantial increase in rates and this in turn would result in a severe burden upon the estates of single persons and married persons not living together at the time of the death of the spouse first dying. The constitutional problein wonld be similar to that under the income tax and would depend upon the constitutionality of taxing the family as a unit. Because of the loss of revenue under this plan and the severity of increased rates when applied to persons unable to take advantage of the proposal, the plan does not appear to merit enactment.

65 I. R. C. $\$ 811(e)$. 


\section{GIFT TAX}

The problem involved under the gift tax law is whether discrimination in favor of spouses in community property states arises from the fact that where a gift of community property is made each spouse is considered to have made a gift of one-half the value of the property. A further problem is whether avoidance of the gift tax takes place through interspouse transfers. Discrimination in favor of spouses in community property states appears to arise from the fact that where a gift of community property is made each spouse is considered to have made a gift of one-half of the value of the property, although the same result may be achieved in non-community property states by transfers from one spouse to the other with subsequent gifts by each of the spouses, or by gifts of property held in tenancy in common, except that in the non-community property states a gift tax liability might have been incurred on the interspouse transfer or creation of the tenancy in common.

A further problem under the gift tax law arises where the separate property of one of the spouses in a community property state is made community by agreement between the spouses. The question arises in California and becomes particularly important in Oklahoma ${ }^{66}$ where the spouses may by filing a written election hold in community, property acquired after the date of signing the election. ${ }^{67}$ In the event that the courts should hold that the Oklahoma community property law is effective to permit the division between spouses of income from community property in that state, the government might well take the position that the spouse from whom the community acquired the property made a gift to the other spouse in the amount of one-half the value of such property at the time of the election. This position would find support in the gift tax regulations holding that if a spouse purchases property with his own funds and has the title conveyed to himself and his spouse as tenants by the entirety and if under local law neither tenant acting alone can defeat the right of the survivor to the whole of the property, there is a gift to the

66 Okla. Sess. Laws 1939, c. 62, art. 2, §1.

67 The Bureau of Internal Revenue has taken the position that the Oklahoma comInunity property law is not effective to permit the division for income tax purposes of the husband's income and petitions and answers setting forth this issue have been filed with the Board of Tax Appeals in the following cases: J. A. LaFortune, No. 107160; Thomas A. Creekmore, No. 107189; J. Wood Glass, No. 108311; John Curran, No. 108445. 
other spouse to the extent of the value of the interest of such spouse in the property. The Treasury gift tax regulations also provide that if a spouse purchases property and has the title conveyed to himself and wife as joint tenants, with rights of survivorship, but which rights may be defeated by either party severing his interest, there is a gift to the wife in the amount of one-half of the value of such property. ${ }^{69}$ The Treasury regulations place emphasis upon the right of survivorship in the case of tenancy by the entirety and the right of severance in the case of joint tenancy. With respect to community property there is survivorship in some states but not in others. The right of severance does not exist in any state except where both spouses agree to it. Consequently, it might be argued that a taxable gift does not take place where spouses in Oklahoma elect to hold as community their property acquired after the date of their election, despite the fact that all of that property was acquired by the community from the separate property or separate earnings of one of the spouses. The solution of this problem will apparently depend upon the interpretation of the Oklahoma community property law itself.

\section{Differences between the Incidence of Federal Gift Taxation in Community Property States and in Other States}

Non-community property states.-The federal gift tax is imposed upon the transfer of property by gift. Where property is transferred for less than an adequate and full consideration in money or money's worth the excess of the value of the property over the value of the consideration is "deemed" a gift. ${ }^{70}$ It must be noted that the tax applies only to gifts made by individuals. ${ }^{71}$ Consequently, a gift by a partnership would apparently be a gift by the individual partners in proportion to their interests in the property given. ${ }^{72}$ If the rule that the gift tax and estate tax "are in pari materia and must be construed together"73 is followed, then, since the gift tax law itself is

68 U. S. Treas. Reg. 79 (1936) arts. 2, 19(8). The validity of the regulations has been upheld. Lilly v. Smith (C. C. A. 7th, 1938) 96 F. (2d) 341; Commissioner v. Hart (C. C. A. 3d, 1939) 106 F. (2d) 269; Commissioner v. Logan (C. C. A. 3d, 1940) 109 F. (2d) 1014.

69 U. S. Treas. Reg. 79 (1936) art. 2.

70 I. R. C. $\$ \S 1000,1002$.

71 U. S. Treas. Reg. 79 (1936) art. 1.

72 See 2 Montgomerx, Federal Tax Handbook, 1940-1941 (1940) 1980. Cf. Ryerson v. United States (1941) 312 U. S. 405, holding that the beneficiaries of a gift in trust were the donees.

73 Estate of Sanford v. Commissioner (1939) 308 U. S. 39, 44. 
silent on the point, it would appear that the taxation of gifts of property held in joint tenancy, tenancy by the entirety, tenancy in common, or as community property should be solved by reference to the treatment of such property interests under the estate tax law. The tax on gifts by both tenants of property held in joint tenancy or tenancy by the entirety would be apportioned on the basis of the original contributions of the tenants mstead of on a half and half basis, while gifts of property held in tenancy in common would be taxable to the tenants according to their respective interests in the property. A gift by one tenant of property held in joint tenancy would, however, appear to sever the tenancy, making it a tenancy in common with a resulting divided tax.

Community property states. - Where community property is made the subject of a gift each spouse makes a gift of one-half of the value of the property. ${ }^{74}$ It has been held, however, that where, a Texas resident makes an irrevocable assigninent of his interest in life insurance policies on which the premiums have been paid from community funds, the total value of the policies transferred must be mcluded in the gift tax return. ${ }^{75} \mathrm{~A}$ different rule has been held to apply to gifts of community property acquired by California residents prior to 1927 , since under the local law at the time the wife had no interest in the community property other than a mere expectancy, and the husband was therefore held taxable upon the entire fair market value of the property transferred by gift.76

\section{Proposed Solutions}

Reversal of Poe v. Seaborn.-Under the gift tax as under the income and estate taxes one possible solution of the community property problem would be the reversal of Poe v. Seaborn ${ }^{77}$ with the consequent taxation to the husband alone in the case of a gift of community property. Since resort to legislative rather than to judicial means appears preferable with respect to the income tax, a similar method of solving the gift tax problem would appear in order.

74 Marion L. Park v. Commissioner (Aug. 25, 1939) B. T. A. Memo. Docket No. 93227, 93228; cf. Anna Eliza Masterson (1940) 42 B. T.A. 419. See Harriss, GIFT TAXAIION IN THE. UNITED STATES (1940) 52; 2 PAUL, op. cit. supra note 1, §16.17.

75 Blaffer v. Commissioner (C. C. A. 5th, 1939) 103 F. (2d) 489. See 2 PaUd, op. cit. supra note $1, \S 16.11$, calling this case "a rara avis" and concluding that except in Louisiana the wife would be held as a co-donor of the policies.

76 Gillis v. Welch (C. C. A. 9th, 1935) 80 F. (2d) 165.

77 Supra note 45. 
Possible solutions for the community property problem under the gift tax include taxing a gift of community property (1) to the donor unless it be shown that the property originally belonged to the other spouse; (2) to the spouse having management and control of such property; or (3) taxing the spouses in all states as a unit, with respect to gifts of property belonging to either or both of them, and (4) taxing one-half of any gift by either or both spouses to each of them.

Taxing a gift of community property to the donor unless it be shown that the property originally belonged to the other spouse and that the property was not acquired from the donor for less than an adequate and full consideration in money or money's worth.-This proposal would appear to be the logical counterpart of the similar proposal on the estate tax. It would be open to the same objection as the proposals on the estate tax in that it would single out community property for a more severe tax than that applicable to property held in joint tenancy or tenancy in common in non-community property states. This criticism might be met by extending the same treatment to property held in tenancy in common, as well as tenancy by the entirety and joint tenancy. This proposal as so amended would still leave open, however, the possibility of gift tax avoidance by transfers of the separate property of the spouses.

Taxing a gift of community property to the spouse having management and control of such property.-Since this proposal would in some cases impose a gift tax upon one who could not himself make the gift without consent of his spouse, it might be urged that it was arbitrary and therefore a violation of due process. To meet this argument it would seem desirable to provide for apportionment of liability equally between the spouses. An alternative might be the imposition of liability upon the spouse having management and control, unless it be shown that the property originally belonged to the other spouse and that it was never acquired from the spouse having management and control for less than an adequate and full consideration in money or money's worth. The constitutional problem would then hinge merely upon the question of whether the family in community property states may be treated as a unit for gift tax purposes, where there is a gift of community property, as well as for income tax pur- 
poses. In view of the discussion of the income tax, it seems that the proposal would be constitutional.

Since this proposal, like the preceding one, would be confined merely to gifts of community property, it might result in a complaint that its effect would be unduly severe upon spouses in community property states as compared with spouses in other states where the holding of property in joint tenancy, tenancy by the entirety, tenancy in common or as separate property of the spouses might accomplish tax avoidance just as effectively as community property would in the community property states.

Taxing all spouses as a unit with respect to gifts of property belonging to either or both of them.-This proposal is the logical counterpart of mandatory joint returns under the income tax law and the proposal for imposing the estate tax on the spouses as a unit. To neet the objection that such a proposal would constitute a violation of due process it seems desirable to divide the gift tax liability between the spouses in accordance with what would have been their separate gift tax liabilities computed upon gifts of their interests in the property which was the subject of gifts during the taxable year. The proposal would then merely lump the gifts of spouses during the year for the purpose of computing the total gift tax liability of the spouses as a unit. The constitutional question, as in the case of the complementary proposals for the income tax and the estate tax, would hinge upon whether the family may be treated as a unit for tax purposes. As in the case of the complementary proposal for the estate tax, tenancies in common and community property should be treated as joint tenancies are now treated, that is, by granting relief to the extent that it can be shown that the property originally belonged to the other tenant and was never received or acquired by such tenant from the taxpayer for less than an adequate and full consideration in money or noney's worth.

Taxing one-half of any gift by either or both spouses to each of them.-This proposal is the gift-tax counterpart of the income and estate tax proposals for division of the taxable object between husband and wife. ${ }^{78}$ It is open to the same objections as the corresponding proposals under the income and estate tax laws. It would result in a loss of revenue, in the absence of increased rates of taxation, and

78 See Harpuss, loc. cit. supra note 74. 
would unduly burden taxpayers who are either unmarried or married and not living with husband or wife. For those reasons, as in the case of the proposals under the mcome and estate tax laws, the plan does not recommend itself for adoption.

\section{CONCLUSIONS}

It seems clear that the residents of commumity property states and other jurisdictions, ${ }^{79}$ to the extent that our federal tax laws are applicable to them, possess certain advantages over the residents of non-community property states and other jurisdictions not having a community property system with respect to the federal income, estate and gift taxes. The advantage arising from the fact that spouses residing in community property states may divide their earned income for federal income tax purposes is clear. In the case of income from property it is less pronounced, since the residents of non-community property states may hold their property as separate property or in tenancy in common and thereby obtain the same income tax advantages but at a gift-tax price. The residents of the community property states also possess advantages with respect to the estate tax arising from the fact that if the husband dies first only one-half of the community property is includable in his estate. The advantage is only partially offset by the fact that if the wife dies first one-half of the community property must be included in her estate. Residents of non-community property states can achieve a like result by a transfer from the husband to himself and wife as tenants in common or by a transfer of one-half the property to his spouse as her separate property, but this can be done only at the gift-tax price. Under the gift tax a similar advantage obtains in the case of a gift of community property.

If, in addition to the elimination of the advantages arising from community property, it is sought to do away with tax avoidance resulting from interspouse transfers, then a scheme for taxation of the family would seem desirable. Under the income tax law this could take the form of mandatory joint returns. ${ }^{80}$ Under the estate tax the corresponding proposal would be to tax all the property of the spouses, in whatever form held, as the property of the spouse who

79 Territories or possessions of the United States and of foreign countries having a community property system.

80 See James, Irascible Comments on the Revenue Laws (1941) 9 CHI. L. REv. 58; Magill, The Federal Income Tax on the Family (1941) 20 TEx L. REv. 150. 
dies first and under the gift tax it would result in taxing spouses as a unit with respect to gifts of property belonging to either or both of the spouses. These proposals would, however, result in a considerable increase in the tax burden of niany married couples at a time when taxes are already extremely heavy. If niandatory joint returns are adopted it would seem advisable to cushion the shock by a separate rate schedule or some form of credit in cases where both the husband and wife have separate sources of income. ${ }^{81}$ Another serious difficulty arises from the fact that in many instances gift taxes have been paid upon interspouse transfers. Sonie relief for such cases would appear in order. To pernit narried couples to divide equally between them the combined nicome of the spouses would result in considerable decrease in revenue and if corresponding provisions were adopted for estate and gift taxes, an additional decrease in revenue would result which would have to be made up by an increase in the rates thus burdening single persons and married persons not living together. For this reason such a solution would not appear desirable.

If, however, it is sought merely to take away the advantages of the residents of the community property states it appears that the result can be best achieved under the income tax by taxing all comnunity income to the husband, except for income earned by the wife or derived from her separate property or property over which she has inanagement and control. Under the estate tax the companion provision would be one following the lines of the present law applicable to joint tenancies and tenancies by the entirety and under the gift tax the gift would be taxed to the donor unless it be shown that the property originally belonged to the other spouse.

The constitutional problems of these proposals do not appear insurnountable. It seems clear that the Supreme Court would uphold a provision of the mcone tax law based upon the taxation of the family as a unit despite the assertion that the taxation of one person on the inconie of another violates the due process clause of the Fifth Anendment. If the family can be classified as a unit for income tax purposes, it would seem that the same is true as to the estate and gift taxes.

81 This should not be confined merely to an earned income credit as suggested by the Treasury in connection with the Revenue Act of 1941. 